Concept Paper

\title{
Dealignment: Class in Britain and Class in British Sociology Since 1945
}

\author{
Ken Roberts 1 \\ Law and Social Justice Building, University of Liverpool, Liverpool L69 7ZA, UK; k.roberts@liverpool.ac.uk \\ or kenneth.roberts18@btopenworld.com
}

Received: 28 September 2020; Accepted: 12 October 2020; Published: 15 October 2020

\begin{abstract}
This paper sets changes in Britain's class structure since 1945 alongside the parallel sociological controversies about class. Since the 1970s, the class scheme developed by John Goldthorpe and colleagues for initial use in their study of social mobility in Britain has become sociology's standard template for thinking about and researching class. Versions have been adopted by the UK government and the European Union as their official socio-economic classifications. This paper does not dispute that the Goldthorpe scheme is still the best available for classifying by occupation, or that occupation remains our best single indicator of class, or that a constant class scheme must be used if the purpose is to measure trends over time in rates of relative inter-generational mobility. Despite these merits, it is argued that the sociological gaze has been weakened by failing to represent changes over time in the class structure itself and, therefore, how class is experienced in lay people's lives. There has been a relative neglect of absolute social mobility flows (which have changed over time), and a pre-occupation with the inter-generational and a relative neglect of intra-career mobilities and immobilities.
\end{abstract}

Keywords: class; class schemes; economy; labour markets; social mobility

\section{Introduction}

This paper sets changes in Britain's class structure since 1945 alongside the parallel sociological controversies about the measurement of class. It is argued that the sociological gaze has been weakened by opting for the dubious advantages of using the same class scheme(s) to identify changes over time, by focusing on relative social mobility and neglecting absolute social mobility flows, and a related focus on inter-generational and relative neglect of intra-career mobility, hence the case for realigning sociology's class schemes with the 21st century class structure

\section{Class in Sociology}

Until the 1960s, in British sociology, class was usually represented by the Registrar General's class scheme. This was originally developed to analyse the 1911 census (see Table 1, left column). The division between classes $3 a$ and $3 b$ was introduced in 1921. This scheme grouped occupations into bands according their social standing. In the late-1940 Hall and Caradog Jones [1] developed an alternative 7-point scheme, which also banded occupations according to their social prestige. The Hall-Jones scheme was based on more thorough research than the Registrar General's classes and was used to analyse Britain's first social mobility survey [2], but was rarely used subsequently. When sociologists wrote about the working class, they were invariably referring to RG classes $3 b-5$. Sometimes, conceptually innovative sub-sections were identified-typically 'new' and 'affluent'. Lockwood [3] identified four ideal typical working class 'images of society' which reflected employees' work and neighbourhood milieu. Jackson and Marsden [4] identified a 'sunken middle class' within RG classes 3b-5. 
Table 1. Class schemes.onfirmed.

\begin{tabular}{cccr}
\hline Registrar General's Social Classes & Market Research & Goldthorpe/NS-SEC & Great British Class Survey \\
\hline 1.Higher management and professional & A. Higher management and professional & 1.Higher management and professional & 1.Elite \\
\hline 2.Lower management and professional & B. Lower management and professional & 2.Lower management and professional & 2.Established middle class \\
\hline 3a. Other non-manual & C1. Other non-manual & 3.Intermediuate office, sales, laboratory & 3.Technical middle class \\
\hline 3b. Skilled manual & & 4.Self-employed & \\
\hline 4. Semi-skilled & C2. Skilled manual & 5.Skilled, technicians, supervisors & 4.New affluent workers \\
\hline 5. Unskilled & D. Other manual & 6.Semi-routine & 5.Traditional working class \\
\hline & & 7.Routine & 6.Emergent service workers \\
\hline & E. Never worked, long-term unemployed & 8.Never worked, long-term unemployed & 7. Precariat \\
\hline
\end{tabular}

NS-SEC: National Statistics-Socio-Economic Classification.

The market research industry had its own 6-point class scheme (Table 1, Column 2), closely resembling the Registrar General's, but purporting to band households according to their typical levels of income and spending practices. The industry has continued to use this scheme. It is also still used in the polls of political opinion that are reported in the press.

By the 1970s, British sociologists were expressing dissatisfaction with all the existing class schemes but had not agreed on a replacement. The main protagonists were a Nuffield (Oxford) group led by John Goldthorpe who produced the scheme in the third column of Figure I, and a Cambridge group who favoured a continuous class scale with no horizontal divides, able to locate every occupation precisely [5]. The Goldthorpe scheme groups occupations according to their typical work (employment relations) and market situations. The most obvious differences from the Registrar General's scheme are the clearer divide between professionals and managers, and 'intermediate' lower-level non-manuals, and the separate class for the self-employed who, in other schemes, have been classed with employees in their occupations. North American sociologists have generally preferred scales (based on prestige, typical incomes or education) but the Wisconsin-Madison-based Erik Olin Wright developed a scheme that groups employers into three classes depending on their number of employees (if any), and classes employees according to the levels of authority attached to their jobs and any job-relevant qualifications held [6]. The performance of the Wright and Goldthorpe schemes was compared in Marshall and colleagues' [7] survey of class in Britain. The Goldthorpe scheme was judged to perform the better insofar as it produced the strongest relationships with variables expected to be predicted by class such as subjective class identities and political partisanship. Wright's purportedly Marxist class scheme has not been used subsequently in any class surveys in Britain.

In Britain, and across Europe, the clear winner in the debates about schemes and scales has been the Goldthorpe scheme in that a slightly amended version has been adopted as the government's official socio-economic classification [8], and another slightly changed version has been adopted by the European Union for assembling harmonised data from member (and other) countries [9]. However, the debate between 'schemers' and 'scalers' took place until the end of the 20th century [10-13]. Schemes place units (individuals or households) into groups that are treated as categorical classes which, in all research influenced by Marxist and/or Weberian approaches, are treated as being formed relationally: employers and employed, managers and managed, and so on. Scales conceptualised class gradationally, with positions ranked on a continuous gradient along which divisions are arbitrary, introduced purely for descriptive or analytical purposes.

The initial use of the Goldthorpe scheme was in a 1972 social mobility survey [14], and a main subsequent use has been in updating the 1972 findings and comparing mobility rates in different countries. This research has produced one of sociology's most startling findings, namely the stability of relative social mobility rates over time $[15,16]$. Relative mobility means social fluidity: the relative chances of individuals with different class origins reaching a given class destination. The stability finding is counter-intuitive given the huge 20th century changes in the economy, labour markets and education. The finding is also puzzling because, to date, sociology has no plausible explanation. Economists have intervened in social mobility research, grouping the population into income bands rather than occupational classes. The economists have confirmed 'the constant flux' except for a decline 
in relative social mobility between Britain's 1958 and 1970 birth cohorts [17]. This is another startling finding, given the otherwise consistent 'constant flux' results, and remains another puzzle to which, to date, there is no explanation that satisfies all the interested parties [18].

During the arguments between schemers and scalers, there have been a couple of shorter-lived but equally acrimonious debates. One, to date unresolved satisfactorily, has been in response to claims that 'class is dead', that the term has ceased to do any useful work for sociology and has become a zombie concept [19-21]. Exponents of class analysis have necessarily rejected these claims, deeming them implausible at a time when economic inequalities have been widening. They have also demonstrated that people remain as willing as ever to talk about classes and to identify with one if prompted sufficiently and appropriately. We shall see that rejecting the 'death of class' claim has not been wrong, but too absolute, insufficiently nuanced.

Another debate has been about how to integrate women into class analysis, the unit to be classed - the individual or the family household - and, if the latter, whose occupation and which other indicators (if any) should be taken into account [22-26]. Advocates have shown that using multiple indicators creates a class variable with stronger predictive power (vis-à-vis children's educational attainments, for example) than occupation alone [27]. Despite this, the pragmatic response of most class researchers has been to classify individuals, not households (though it is households that do the most consumption and socialise children), and to classify by occupation alone, using the occupation of the main earner when wishing to classify an entire household. Using multiple indicators, and more than one individual's occupation, necessarily results in a class scale, not the kind of categorical, relational scheme which most British sociologists have preferred. We shall see that insisting on the individual's occupation as the starting point has not been an error in class analysis so much as the failure eventually to look beyond at the household.

Alongside the above debates about how to identify class positions and the related research, mostly quantitative, there has been a healthy stream of generally smaller-scale enquiries into people's views and feelings about class and their own social locations (for example, Skeggs [28]). In the 1990s, Crompton [29] appealed for the quantitative and qualitative steams of research and findings to be drawn together. They were connected in a surprising way in 2013 in the Great British Class Survey (GBCS) [30,31]. This launched a class questionnaire on the BBC's website, in collaboration with the broadcaster, and addressed questions about respondents' economic resources, social capital (the occupations of people they knew), and cultural tastes. The choice of questions was said to be inspired by the work of the French sociologist, Pierre Bourdieu, though the GBCS did not follow Bourdieu's own research methods. Measurements of the different assets were used to produce clusters to which the investigators affixed the class labels in the right column of Table 1.

The GBCS was the first attempt in almost 50 years to create an alternative to the Goldthorpe class scheme, which (for good reasons, as we shall see) the GBCS investigators considered outdated. However, the GBCS is best treated as answering a set of 'What if ... ?' questions rather than a finalised, definitive class scheme. What would be the response to an online class survey launched on the BBC's website? The response was massive and produced sufficient numbers to analyse in small groups of occupations and sometimes single occupations. The limitation was that the response was not representative, which was remedied by following the online survey with a smaller representative sample. Another 'What 'if?' was about the outcome of mixing economic, social and cultural indicators. The result is an interesting map of Britain's economic and socio-cultural landscape in the 21st century but, as argued below, not a true class scheme. Needless to say, this verdict depends on how we choose to define class.

\section{Defining Class}

If the concept is to do useful work, we must insist that class is about inequalities, not all differences (in tastes, choices of friends, uses of free time and geographical location, for example). Moreover, only inequalities rooted in the economic systems of production, distribution and consumption should 
be treated as class inequalities. Patriarchy and racial inequalities may intersect with class divisions, but they are different- they do not have the same roots as class inequalities. This narrow definition has always been implicitly accepted by class researchers, which is why the use of occupation as the best single indicator of class has so rarely been challenged (for a recent vindication see Williams [32]). The individual must be the primary unit that is 'classed', since it is usually individuals who are employed or self-employed, and who earn incomes. It is also individuals who access class positions on the basis of their educational attainments, and who possess tastes, attitudes and political proclivities. Family households are the normal (though not the only) units of consumption, and so should eventually be drawn into class analysis, but the start-point must be the individual. Education and types of housing are relevant as the causes and outcomes of the occupancy of class positions, but alone they do not form populations into classes. Income is certainly relevant, but lifetime income is more relevant than current income, and occupation is the superior predictor of the former. Most basically, therefore, classes are groups of occupations, and the individuals who occupy these positions and thereby have common locations in the economic order. To this, we may add:

1. The common positions must be sustained, Ideal Type throughout working life. This does not necessarily mean staying in the same occupation. The common experience may be of continuous career progress, or settling on a plateau, or persistent vulnerability;

2. In order to be regarded as demographically fully formed, members of a class should also have characteristic and distinctive social origins in classed families and education;

3. Their children should enjoy class-characteristic life chances.

Once all the above conditions are met, we can say that a class has achieved demographic coherence, that is, it has become a distinct sub-population. This coherence is not an essential pre-requisite, but it will be propitious for a class to become a socio-cultural entity in which intra-class acquaintanceships, friendships and family ties greatly exceed those between classes, and for this sub-population to develop class-characteristic beliefs, tastes and related practices, and political preferences. Unless nested in economically based classes, closed socio-cultural networks are just lifestyle groups, not social classes.

The above list of conditions may lead to doubts over whether it will be possible to identify any classes in Britain today. However, in the mid-20th century Britain had two classes, a middle class and a working class, that met all the criteria. This will be why sociologists were content for so long to use the Registrar General's class scheme that could be collapsed into just two classes. Class in the 21st century is different. Thus, we can recognise immediately that classes change along with an economy. Classes are always most likely to be in formation or dissolution. Some classes may be dying while others are strengthening. This is why claims that class is dead or still alive should always be nuanced. This is also why it is essential, not just a useful add-on, to build a historical dimension into class analysis. Hence, the following passages compare the class structures that awaited new entrants to the workforce in the decade following the Second World War, their children who typically entered the labour market in the late 1970s and early 1980s, and the latest generation who made their education-to-work transitions in the 2010s.

\section{Class in Britain}

\subsection{Late 1940 s to 1970 s}

Sociology possessed a conceptual toolkit that could handle the main changes in Britain's class structure throughout this post-war period and could identify the drivers of change, except at both ends of the class structure. None of the schemes or scales had a class above managers and professionals, though Goldthorpe's adoption of the term 'service class' implied the existence of a class above the one that was being serviced. Whether there was a separate capitalist class, or whether its power had been redistributed in a managerial revolution, the continued significance (if any) of the traditional upper class, and whether Britain was run by a discreet establishment, were bracketed aside from mainstream class research and theory. Full employment and the welfare state were supposed to have 
eradicated a rough underclass, and the study of any who were 'falling through the nets' was left to social policy experts.

The formation of a working class that had begun over a century before was reaching its zenith in the 1950s (see Thompson, [33]), and likewise the formation of a unitary middle class among those who felt threatened rather than represented by working class power [34]. The link between class and voting was then at its strongest ever, though none of this was known at the time. There were debates about whether the working class was being changed by affluence, improved housing and other benefits of the welfare state. Various new working-class factions were identified, but all researchers agreed that embourgeoisement (assimilation into the middle class) was not occurring $[35,36]$. The most significant long-term change was that the working class was declining as a proportion of the workforce. This was due partly to globalisation (though this term was not used at the time). Britain was importing more of the manufactured goods that it consumed. In the late 1940s, there were still scores of textile mills across East Lancashire and West Yorkshire. By the end of the 1950s, most were derelict. Textiles were being imported from the Far East. Britons then began riding Japanese motor bikes, then Japanese cars, plus models manufactured in Germany, Italy and France. Washing machines and other 'white goods', together with televisions and other electrical appliances, became imports rather than local manufactures. The effects were amplified by technological change. 'Automation' in factories was replacing workers with machines. Until the 1970s, this did not result in unemployment. The working-class jobs that were lost were more than replaced by a growth in middle-class employment (see below). From the 1940s to the 1960s, governments prioritised full employment in their economic policies. Whenever the claimant count rose towards half a million, measures were taken to strengthen labour demand.

School-leavers who started work in the post-war decade rarely entered 'jobs for life'. Job changing was frequent. People moved for better pay, more interesting work, to be closer to home or transport routes, or just for a change. Towards the end of their working lives, very few were in the same occupations that they had entered as teenagers [37,38]. Throughout the early and mid-points of this cohort's working lives, income inequalities were narrowing-between working-class and middle-class jobs, between skilled and other working-class jobs, and between youth and adult earnings. Everyone's real wages were rising. More married women were earning a second income. Working-class families were able to move from privately rented terraced houses into new-built council houses or owner-occupied semi-detached dwellings. Homes became better equipped with soft furnishings, carpets, domestic gadgets and televisions. Car ownership became normal during the 1960s. Teenagers who left school at age 15 or 16 without any qualifications were part of these developments. When immigration from the non-white Commonwealth began to turn Britain into a multi-ethnic society, the newcomers moved into jobs and housing that were being vacated by the white working class.

However, difficulties in sustaining working class careers became increasingly common during the 1970s due to closures of entire shipyards and car plants that had been the main sources of local employment [39,40]. They were followed by steel mills and coal mines [41]. The post-war working-class cohorts of beginning workers often experienced undignified, tattered conclusions to their working lives $[42,43]$. Those who had served apprenticeships believing that this made them skilled for life often found that this was not the case [44].

By the late 1970s, working-class 16- and 17-year-old school-leavers were finding it difficult to enter the labour force. Youth unemployment had become a problem which was being addressed by a succession of special measures. There had been a voluntary element to much youth unemployment up to the 1970s. Young people would work for a bit in order to do nothing for a while. Neither jobs nor unemployment were considered tolerable for long unbroken periods [45,46]. Unemployment in local youth labour markets needed to rise above 30 percent before long-term joblessness began to rise steeply, which was becoming more and more common by the early 1980s [47]. However, it was poorly qualified and completely unqualified 'early' (16- and 17-year-old) school-leavers who were affected. There were still jobs for decently qualified 16- and 17-year-olds from all social backgrounds. 
The decline in manual (working class) employment during the post-war decades was more than compensated by an expansion of non-manual jobs. The growth was at all non-manual levels. The first technological revolution in the modern office was introducing electric typewriters and duplicating machines that had to be staffed. Employing organisation were becoming larger. Commercial businesses had an insatiable demand for office staff. The recruits were mostly young women. There was also a demand for more managers and professionals to coordinate the work of large organisations and to design then supervise the installation and operation of new machines on factory floors. Public sector employment was growing in some industries which had been taken into public ownership (gas, electricity and telecommunications, for example), and in health care, education and other branches of the welfare state, and in general public administration. Young people who embarked on middle-class careers in the 1940s and 1950s were able to rise with the expansion of their occupations. They are now referred to as a lucky generation who could benefit from the post-war welfare state which offered free education at all levels including university, and (means-tested) student maintenance grants were also available. University graduates and 16-18-year-olds with secondary school qualifications had no difficulty in obtaining commensurate non-manual employment, and since the 1990s, some have been able to retire with inflation-proof, final salary-linked pensions.

In the 1940s, only three percent of young people went to university. Participation rose steadily but had reached only 15 percent in 1980 . The 15 percent includes those who gained degree-level qualifications at non-university institutions, usually colleges of higher education and polytechnics. In the 1970s, university graduates were still considered an elite [48]. At the beginning of the 1980s, only a third of the workforce (not an entire birth cohort) occupied management and professional jobs from which they have subsequently been able to retire on pensions linked to final salaries which have guaranteed prosperity throughout their later lives.

Employers invariably wanted recruits to all levels of non-manual employment to offer proof of the required abilities and aptitudes by having gained at least secondary school qualifications. However, even after the 1944 Education Act, only around a quarter of all young people were attending the grammar schools that entered pupils for public examinations. It was inevitable that employers would recruit into non-manual jobs young people who could display some other evidence of the required capabilities. By the early 1960s, only eight percent of young people were obtaining university-level qualifications. The professional and management grades then accounted for around a quarter of all jobs. There had to be other routes into these grades. It was possible until the 1960s for young people to complete full-time education at 18, 16 or even 15, then to study on day release and at night school and eventually become fully qualified solicitors and accountants. Most professional engineers gained their qualifications through the 'alternative route' offered by further education. However, this changed during the working lives of young people who entered the workforce in the 1940s and 1950s. During the 1960s, all the major professions began to restrict entry to higher education graduates. They saw this as necessary to maintain or preferably boost their status. Large corporations began to recruit university graduates as management trainees. As this practice became widespread, young people who started their working lives at 16-18 in the office or the works faced a strengthening promotion blockage, the graduate barrier. In the 1950s, Lockwood [49] noted that clerical work had become less attractive to young men. This was the context in which Lockwood's black coated clerks were being replaced by white-bloused staff. Britain's Equal Pay Act was still in the future (1970) and the Equal Opportunities Act was not passed until 1975. At that time, Crompton and Jones [50] found that male recruits in offices were usually doing administrative tasks (not typing) and were being groomed for promotion to management. The office girls had become, in effect, a white-collar proletariat.

\subsection{Early 1980 s to 2020 s}

Goldthorpe and his co-researchers were reading ongoing trends correctly in the early 1970s when they created their class scheme. There was nothing novel in the rank order of occupations. The main innovation was the clear division between managers and professionals as a distinct class 
above other non-manual occupations, which were classed as intermediate. Lower-level management and professional jobs were referred to as cadet grades, from which beginners could rise to higher levels. The obverse situation was that ascent from the intermediate class was far less likely. In this respect, the Goldthorpe scheme was correct at the time, but it misrepresents the situations during earlier decades in the 20th century when occupations at that time are classed into this scheme. Earlier on, lower non-manuals had been part of a tiered but unitary middle class. As we shall see below, the division between a unitary service class and other non-manuals also misrepresents the class structure in the 21st century. The Goldthorpe scheme's other innovation was to group all the self-employed into one intermediate class. This has always been controversial, since the self-employed may be accountants, plumbers or jobbing domestic cleaners. Grouping all the self-employed together looks completely inappropriate in the 21st century, with an earlier decline having been reversed and the numbers having risen from less than 1.5 million in the 1970 s to over four million.

We can note that, in the 1970s, all non-manual occupations remained unlike working class jobs, in that the former offered progressive careers, some short, others long. Non-manuals also enjoyed the greater employment security. Up to the end of the 1970s, non-manual careers were not ending in tatters. Secondary school qualifications earned entry to secure, progressive careers in non-manual jobs. A university degree was a certain route into management and professional careers, though this was still not the only route upwards for young people from lower-class origins. A university qualification guaranteed that young people from service class families would maintain their parents' socio-economic positions. We shall see that this began to change in the 1980s, by which point the children of beginning workers in the late 1940s and early 1950s had embarked upon their own working lives.

The changes in Britain's class structure since school- and college-leavers in the late 1970s and early 1980s commenced their working lives have been just as unforeseen and unpredictable, but more thorough, than the changes that had occurred up to then during their parents' working lives. Old and new change drivers have subsequently been at work.

There has been another wave of new technology - ICT — which has been unprecedented in affecting virtually all occupations and all business sectors:

1. Globalisation has been more comprehensive: with increased flows not just of goods, but also trade in services, and flows of information, people and capital;

2. By the 2010s, Britain differed from all other European countries in having experienced over 30 years of neo-liberal economic and social policies. This meant deregulating markets, prioritising low inflation over low unemployment in macro-economic management, transferring assets and activities from the public to the private sector, enfeebling trade unions, and constant downward pressure on all public spending, including means-tested welfare benefits, so as to make even low-paying jobs preferable to unemployment;

3. The sizes of the population and workforce have grown due to natural increase, immigration from pre- and post-2004 European Union countries, and the rest of the world. Female workforce participation has continued to rise. The workforce has become much better educated. By the early 1990s, over 30 percent of 18-20-year-olds were entering higher education. By 2020, it was 40 percent and by age 30, half of the workforce had a higher education qualification.

\section{Class in the New Millennium}

The changes with the most widespread consequences have been at the top where the catalyst has been the globalisation of financial flows combined with the deregulation of the UK's finance businesses. In 1979, all controls were removed from the import and export of capital [51]. During the 1980s, financial markets were liberalised in a cascade of deregulation. Foreign banks were allowed to base in and trade from London. Statutory distinctions between high street banks and building societies were scrapped, and likewise between high street and investment banks. Banks were allowed to trade on their own accounts as well as on behalf of customers. New financial products were invented which banks could sell to retail customers, and to one another-bundles of loans and futures, and credit 
default swaps, for example. New forms of ICT-enabled trading were pioneered, most spectacularly high-velocity trading controlled by computer algorithms which can buy and sell assets within seconds. Britain's financial services expanded remarkably in terms of volume of business and geographically. 'The City' spread beyond the traditional square mile around the Bank of England into an area to the east, formerly mostly wasteland, known as the Isle of Dogs, but now better known as the site of Canary Wharf. Foreign capital was attracted to London by the City's expertise in delivering returns on investments, exporting funds when desirable and, when appropriate, using Britain's overseas territories where tax rates are low and levels of bank secrecy are high [52].

There have been several far-reaching consequences. The effectiveness of finance businesses in securing returns on investments has helped to tilt the distribution of UK and global GDP away from labour and towards capital. In Britain, the percentage going to labour has fallen from over 60 percent in the 1970s to around a half today. This has been one source of the downward pressure on real wages and salaries, which started at the bottom then spread upwards. An outcome is that current cohorts of young people cannot expect to live as well as their parents [53]. They earn less than their parents in real terms and occupy inferior housing at all ages up to 30, and will continue to do so.

A second consequence has been the financialisation of swaths of Britain's corporate economy [54]. Company shares have become primarily financial assets which are bought and sold in search of capital gains. Breaking-up and merging parts of or entire businesses happens if this maximises returns to investors who force businesses to become flexible. Company law in Britain requires that directors prioritise shareholders' interests.

A third consequence has been to separate an upper middle class from other professionals and managers. Investment banking is able to yield extraordinarily high earnings per employee, who can be paid spectacular salaries and bonuses. Investment banks, and the investment sections of multi-function banks, are de facto employee cooperatives. By the end of the 1980s, the rest of Britain was eyeing with awe and amazement the new 'masters of the universe', who could earn more in a year that the typical worker earned in a lifetime [55]. These rewards are shared with the law and accountancy firms that service the finance sector, and with company directors and senior managers who deliver returns on investments.

In 2017, average annual earnings in Britain for full-time employees were approximately GBP 27K. Anyone with an income above GBP 60K was in the top 10 percent, and above GBP 90K in the top five percent. A leap to GBP $170 \mathrm{~K}$ was necessary to join the top one percent [56]. Most employees earn between GBP $15 \mathrm{~K}$ and $40 \mathrm{~K}$. Above this there is a long, slowly tapering income spire. Medicine, dentistry, vets, university staff and engineers are among the professions that have become part of this spire. We know a great deal about the recruits to careers that can lead up the spire [57-59]. They are from a limited number of universities: Oxford, Cambridge and the main London universities are the best represented. These universities are distinguished by the relatively high proportions of their undergraduates from independent and other academically selective secondary schools, whose pupils tend to be from upper-middle-class families. Upper-middle-class parents are able to pay for whatever will enhance their children's life chances. This upper middle class has rapidly become Britain's most demographically coherent class with a distinctive corporate class consciousness [60].

The financialisation of corporations and ICT have changed the character of employment careers at all levels beneath the upper middle class. Middle and junior managers have merged into other non-manuals who are engaged in sales, marketing and accounts, all using computers and monitored constantly by the technology. They manage data and one another-no-one else. Promotion into the upper middle class of senior managers has become a remote possibility. Staffing levels in offices have been decimated as ICT has eliminated typing and filing. Until the 1980s, staff recruited to all these jobs started on career ladders up which they could expect to progress and on which they would remain unless offered more attractive jobs. These career ladders have gone. They have been replaced by annual or more frequent progress reviews and performance-related pay [61-63]. Redundancies, formerly associated with the working class, have become normal and expected in flexible offices as 
businesses have merged and delayered. Demands for savings on staff costs are now regular challenges. Almost everyone employed in such organisations believes that, at some point, they are likely to be declared redundant $[64,65]$. The upper middle class has not been immune, but their severance packages usually ensure that their lifestyles are not threatened. Most higher education graduates enter and will remain in the lower middle class, but the jobs are also filled by starters with lower qualifications. These are the jobs for which graduates feel that they are over-qualified, and their employers agree [66]. Average starting salaries for all UK graduates are currently GBP 20K. Those recruited to careers that are expected to lead into the upper middle class start on GBP 28K or higher - much higher, GBP 45K or more, in investment banking. The typical graduate's career will remain within the middle salary band of from GBP $15 \mathrm{~K}$ to $40 \mathrm{~K}$.

The professions have remained relatively secure occupations. New technology has been used to enhance human capabilities rather than replace labour, and specialist skills and experience are never easy or cheap to replace. However, despite becoming all-graduate, only some professions have been able to claim upper-middle-class status and salaries. There is now a distinct class of 'other professions' - school-teachers, librarians, professions allied to medicine, social workers and so on. Progression into the upper middle class is exceptional, not a normal career expectation.

There is still a working class. It makes 'stuff', not data, and moves stuff, human and inanimate. As always, the working class is tiered. There is now a distinct upper working class. These jobs are classified as skilled. Training is basically in workplaces, complemented by sessions 'off-the-job', and certification has become normal and typically required. This upper working class is much slimmer than the working class of the past, but has fared rather well since the closures of factories, mines and shipyards in the 1970s and 1980s. The class is employed in aerospace, munitions, motor vehicle assembly and the production of components, steel plants that have survived into the 21st century, car repairs, oil refineries, energy generation and distribution, telecommunications, public transport and private haulage businesses. Most workforces on large sites are represented by trade unions. Rates of pay are above average, equal to those in 'other professions'. Redundancies followed by tattered ends to working lives are still a possibility if and when a site closes, but sites that survived the 1970s and 1980s have done so by being internationally competitive and their workforces are faring rather well.

Britain's fastest growing class over the last 30 years has been a precariat (identified by Standing, [67]). The occupations can be precarious in any of several ways. The jobs may be for shorter hours than the employees want. The jobs may be of finite duration. Employers have become unwilling to pay for more time than they really need. The rates of pay may offer only precarious livelihoods, a little above, at or beneath the levels at which employees become eligible for means-tested state benefits. The minimum pay that became law in 1999, complemented by the living wage for over-25 year-olds, have become regarded as decent pay. Anything higher is 'good pay'. These thresholds have sunk as governments have sought to pressure the unemployed into low-paid jobs. Around a quarter of Britain's workforce is eligible for means-tested benefits. Twenty percent of households are officially defined as living in poverty (beneath 60 percent of median income moderated for household size and composition). These households are most likely to include working-age adults. A third of children are being reared in these households. Food banks have become normal parts of town and city landscapes.

The precariat includes many members of Britain's growing army of self-employed, for whom this has been an enforced last resort rather than evidence of a blossoming enterprise culture [68-70]. They are domestic gardeners, cleaners, and delivery drivers. The employed precariat work in retail, distribution depots and hospitality. The precariat has grown as employment protection has weakened while trade union membership has fallen, amid a growing supply of labour from women returners and others displaced from lower-middle- and working-class careers, and immigrants.

This has become a demographically coherent class. For some, precarious employment is their first step into the workforce. For some it is a steep downward step at any point from mid-working life onwards. However, for others it has become a career-long position as less-qualified beginners have found that former routes upwards have been broken [71-75]. The least qualified school-leavers 
have become distinctly tail-end, around 20 percent of the age groups who leave education without any qualifications that will assist in their searches for work [76]. This 'tail' is drawn mainly from Britain's least advantaged, poorest families. By age 30, they are rearing a successor generation of disadvantaged children. This means that the precariat is not a collection of individuals, though there are such persons, for whom precarious employment is a first step into the workforce, or positions into which they descend in their mid- or late-career. There is now a demographically well-formed precariat class for whom precarious employment is their main career-long position. This class is drawn from children reared in Britain's most disadvantaged families, and rears a successor generation of disadvantaged children. This class has a distinctive position in the regimes of economic production, distribution and consumption.

Britain's precariat has borne most of the pain in the recession that followed the 2007-2009 financial crisis and post-2010 governments' austerity policies [77-80]. This recent pain has been superimposed onto a longer-term trend.

\section{Discussion and Conclusions}

The class structure awaiting Britain's young people in the 2000s has been quite unlike the class structure that awaited their parents in the late 1970s and early 1980s, which was then very different from the class structure entered by beginning workers in the 1940s and 1950s (see Table 2).

Table 2. Changes in the class structure.

\begin{tabular}{ccc}
\hline 1945s-1960s & 1970s-1990s & 21st Century \\
\hline & & Upper middle class \\
\hline Middle class & Service class & \\
\hline & Intermediate occupations & Lower middle class: other professions and non-manuals \\
\hline Working class & Working class & Upper working class \\
\hline & & Precariat \\
\hline
\end{tabular}

The actual class structure is less clearly divided than Table 2 suggests. Initially, it must be individuals who are classed, but family households need eventually to be drawn into the picture: they are important units of consumption. Family households may be classed by the positions of their main earners, which always increases the proportions of units in higher income and reduces the proportions in lower income classes. Alternatively, and more realistically, the occupations of all earners can be taken into account. There are always cross-class households, but the tendency for like to marry like, and for children to stick close to their parents' class positions, creates 'clumps', the core members of each class, and 'valleys', in which classes merge into one another. The tendency for family members to share common class positions simultaneously widens the distance between the classes at the top and in the middle, and between the latter and those at the bottom of the structure.

It is necessary to use a single class scheme to compare the rates of relative social mobility between times and places. The stability of these rates is an important and startling finding. However, a class scale divided into quartiles would be equally satisfactory for this purpose. Sociology cannot afford to overlook that class structures vary across times and places, and there are advantages in sociology's class schemes representing class as experienced by the members of any society at a specific time.

Intra-generational career mobility will be important in class as experienced. Here, a main change over time has been a loss of employment security, except possibly in the professions. Another change has been the greater difficulty in moving upwards for individuals who enter the workforce without higher education qualifications. As regards inter-generational mobility, in the past, when there was an expanding unitary middle class, or just an expanding service class of managers and professionals, who accounted for around 40 percent of the workforce by the end of the 1980s, mobility from below was quite common, and risks of descent were quite low. Goldthorpe was justified in the 1970s and 
1980s in arguing that movement had to be from the working class into the service class, or vice versa, skipping the intermediate classes, before social mobility could be declared unequivocally to have occurred. In the 2000s, individuals from managerial and professional family backgrounds, and those from the intermediate classes and even the working class, may feel that they have definitely moved up only if they can enter the rather small upper middle class. For anyone from the intermediate and working classes, risks of descent into a new precariat will have become a serious concern and a common experience. We can see immediately why sociology's finding of constant relative social mobility has failed to penetrate the public and political consciousness. Staying close to 'class as experienced' will also increase the likelihood of sociology's terms penetrating public consciousness and debates. The diffidence that people display when asked to class themselves must be due in part to their inadequate class language [81-83]. Sociology can only strengthen its influence by using multiple schemes that closely resemble the class structures experienced by different generations. We might also find that the declining political significance of class in an era of widening inequalities could be an illusion produced by using out-of-date class schemes.

Funding: This research received no external funding.

Conflicts of Interest: The author declares no conflict of interest.

\section{References}

1. Hall, J.; Caradog Jones, D. Social grading of occupations. Br. J. Sociol. 1950, 1, 31-55. [CrossRef]

2. Glass, D.V. Social Mobility in Britain; Routledge: London, UK, 1954.

3. Lockwood, D. Sources of variation in working class images of society. Sociol. Rev. 1966, 14, 249-267. [CrossRef]

4. Jackson, B.; Marsden, D. Education and the Working Class; Penguin: Harmondsworth, UK, 1961.

5. Stewart, S.; Prandy, K.; Blackburn, R.M. Social Stratification and Occupations; Macmillan: London, UK, 1980.

6. Wright, E.O. Classes; Verso: London, UK, 1985.

7. Marshall, G.; Rose, D.; Newby, H.; Vogler, C. Social Class in Modern Britain; Hutchinson: London, UK, 1988.

8. Rose, D.; O'Reilly, K. (Eds.) Constructing Classes; ESRC/ONS: Swindon, UK, 1997.

9. Rose, D.; Harrison, E. The European Socio-Economic Classification: A new social class scheme for comparative European research. Eur. Soc. 2007, 9, 459-490. [CrossRef]

10. Rose, D. Once more unto the breach: In defence of class analysis yet again. Work Employ. Soc. 1998, 12, 755-767. [CrossRef]

11. Blackburn, R.M. A new system of classes: But what are they and do we need them? Work Employ. Soc. 1998, 12, 735-741. [CrossRef]

12. Evans, G. On tests of validity and social class: Why Prandy and Blackburn are wrong. Sociology 1998, 32, 189-202. [CrossRef]

13. Prandy, K.; Blackburn, R.M. Putting men and women into classes: But is this where they belong? Sociology 1997, 31, 143-152. [CrossRef]

14. Goldthorpe, J.H.; Llewellyn, C.; Payne, C. Social Mobility and Class Structure in Modern Britain; Clarendon Press: Oxford, UK, 1987.

15. Erikson, R.; Goldthorpe, J.H. The Constant Flux: A Study of Class Mobility in Industrial Societies; Clarendon Press: Oxford, UK, 1992.

16. Erikson, R.; Goldthorpe, J.H. Has social mobility in Britain decreased? Reconciling divergent findings on income and class mobility. Br. J. Sociol. 2010, 61, 211-230. [CrossRef]

17. Blanden, J.; Machin, S. Recent Changes in Intergenerational Mobility in Britain; Sutton Trust: London, UK, 2007.

18. Bukodi, E.; Goldthorpe, J.H.; Waller, L.; Kuha, J. The mobility problem in Britain: New findings from the analysis of birth cohort data. Br. J. Sociol. 2015, 66, 93-117. [CrossRef] [PubMed]

19. Beck, U. Beyond class and nation: Reframing social inequalities in a globalizing world. Br. J. Sociol. 2007, 58, 679-705. [CrossRef]

20. Pahl, R. Is the emperor naked? Some questions on the adequacy of sociological theory. Int. J. Urban Reg. Res. 1989, 13, 709-720. [CrossRef] 
21. Pakulski, J.; Waters, M. The Death of Class; Sage: London, UK, 1996.

22. Britten, N.; Heath, A. Women, men and class analysis. In Gender, Class and Work; Garmarnikow, E., Morgan, D., Purvis, J., Taylorson, D., Eds.; Heinemann: London, UK, 1983.

23. Charles, N. Women and class: A problematic relationship. Sociol. Rev. 1990, 38, 43-89. [CrossRef]

24. Dale, A.; Gilbert, G.N.; Arber, S. Integrating women into class theory. Sociology 1985, 19, 384-409. [CrossRef]

25. Leiulfsrud, H.; Woodward, A. Women at class crossroads: Repudiating conventional theories of family class. Sociology 1987, 21, 393-412. [CrossRef]

26. Stanworth, M. Women at class crossroads: A reply to Goldthorpe. Sociology 1984, 18, 159-170. [CrossRef]

27. Elliott, J.; Lawrence, J. Refining Childhood Social Class Measures in the 1958 British Cohort Study; Working Paper 2014/1; CCLA Cohort Studies, Institute of Education: London, UK, 2014.

28. Skeggs, B. Formations of Class and Gender; Sage: London, UK, 1997.

29. Crompton, R. The fragmentation of class analysis. Br. J. Sociol. 1996, 47, 56-67. [CrossRef]

30. Savage, M. Social Class in the 21st Century; Penguin Random House: London, UK, 2015.

31. Savage, M.; Devine, F.; Cunningham, N.; Taylor, M.; Li, Y.; Hjellbrekke, J.; Le Roux, B.; Friedman, S.; Miles, A. A new model of social class? Findings from the BBC's Great British Class Survey. Sociology 2013, 47, 219-250. [CrossRef]

32. Williams, M. Occupational stratification in contemporary Britain: Occupational class and the wage structure in the wake of the Great Recession. Sociology 2017, 51, 1299-1317. [CrossRef]

33. Thompson, E.P. The Making of the English Working Class; Penguin: Harmondsworth, UK, 1968.

34. Lewis, R.; Maude, A.U.E. The English Middle Classes; Phoenix House: London, UK, 1949.

35. Goldthorpe, J.H.; Lockwood, D.; Bechoffer, F.; Platt, J. The Affluent Worker in the Class Structure; Cambridge University Press: London, UK, 1969.

36. Zweig, F. The Worker in an Affluent Society; Heinemann: London, UK, 1961.

37. Goodwin, J.; O'Connor, H. Continuity and change in the experience of transition from school to work. Int. J. Lifelong Educ. 2007, 26, 555-572. [CrossRef]

38. Vickerstaff, S. Apprenticeship in the "golden age": Were youth transitions really smooth and unproblematic back then? Work Employ. Soc. 2003, 17, 269-287. [CrossRef]

39. Daniel, W.W. Whatever Happened to the Workers in Woolwich? Political and Economic Planning: London, UK, 1972.

40. Payne, D. Closure at Linwood; Manpower Services Commission: Edinburgh, UK, 1975.

41. MacKenzie, R.; Stuart, M.; Forde, C.; Greenwood, I.; Gardiner, J.; Perrett, R. "All that is solid?" Class identity and the maintenance of a collective orientation among redundant steelworkers. Sociology 2006, 40, 833-852. [CrossRef]

42. Vickerstaff, S.; Cox, J. Retirement and risk: The individualisation of retirement experiences. Sociol. Rev. 2005, 53, 77-95. [CrossRef]

43. Young, M.; Schuller. Life after Work; Harper Collins: London, UK, 1991.

44. Ryrie, A.C.; Weir, A.D. Getting a Trade; Hodder and Stoughton: London, UK, 1978.

45. Parker, H. View from the Boys; David and Charles: Newton Abbot, UK, 1975.

46. Roberts, K.; Noble, M.; Duggan, J. Youth Unemployment: An old problem or a new lifestyle? Leis. Stud. 1982, 1, 171-182. [CrossRef]

47. Roberts, K.; Duggan, J.; Noble, M. Unregistered Youth Unemployment and Outreach Careers Work; Final Report Part One Non-Registration, Research Paper 31; Department of Employment: London, UK, 1981.

48. Kelsall, R.K.; Poole, A.; Kuhn, A. Graduates: The Sociology of an Elite; Methuen: London, UK, 1972.

49. Lockwood, D. The Blackcoated Worker; Allen and Unwin: London, UK, 1958.

50. Crompton, R.; Jones, G. White-Collar Proletariat; Macmillan: London, UK, 1984.

51. Calhoun, C.; Derluguian, G.; Derluguian, G.M. Business as Usual: The Roots of the Global Financial Meltdown; New York University Press: New York, NY, USA, 2011.

52. Tax Justice Network. The Price of Offshore Revisited; Tax Justice Network: London, UK, 2012.

53. Roberts, K. The end of the long baby boomer generation. J. Youth Stud. 2012, 15, 479-497. [CrossRef]

54. Lapavitsas, C. Theorizing financialization. Work Employ. Soc. 2011, 25, 611-626. [CrossRef]

55. Buchanan, A. The Game: How the City Really Works; Elliott and Thompson: London, UK, 2010.

56. HM Revenue and Customs. Personal Income Statistics 2015-16; HM Revenue and Customs: London, UK, 2018.

57. Friedman, S.; Laurison, D.; Miles, A. Breaking the "class" ceiling? Social mobility into Britain's elite occupations. Sociol. Rev. 2015, 63, 259-289. [CrossRef] 
58. High Fliers Research. The Graduate Labour Market in 2018; High Fliers Research: London, UK, 2018.

59. Wakeling, P.; Savage, M. Entry into elite positions and the stratification of higher education in Britain. Sociol. Rev. 2015, 63, 290-320. [CrossRef]

60. Davis, A. Sustaining corporate class consciousness across the new liquid managerial elite in Britain. Br. J. Sociol. 2017, 68, 234-253. [CrossRef]

61. Grimshaw, D.; Beynon, H.; Rubery, J.; Ward, K. The restructuring of career paths in large service sector organizations: "delayering", upskilling and polarisation. Sociol. Rev. 2002, 50, 89-116. [CrossRef]

62. Halford, S.; Savage, M. The bureaucratic career: Demise or adaptation? In Social Change and the Middle Classes; Butler, T., Savage, M., Eds.; UCL Press: London, UK, 1995.

63. R Mills, C. Managerial and professional work histories. In Social Change and the Middle Classes; Butler, T., Savage, M., Eds.; UCL Press: London, UK, 1995.

64. Gallie, D.; Felstead, A.; Green, F.; Inanc, H. Fear at Work in Britain: First Findings from the Skills and Employment Survey 2012; Centre for Learning and Life Chances in Knowledge Economies and Societies, Institute of Education: London, UK, 2013.

65. Worrall, L.; Cooper, C.; Campbell, F. The new reality for UK managers: Perpetual change and employment instability. Work Employ. Soc. 2000, 14, 647-668. [CrossRef]

66. Felstead, A.; Gallie, D.; Green, F.; Inanc, H. Skills at Work in Britain; Institute of Education: London, UK, 2013.

67. Standing, G. The Precariat: The New Dangerous Class; Bloomsbury Academic: London, UK, 2011.

68. Elliott, L. Pattern of employment turns the clock back 500 years. The Guardian, 22 June 2017; 23.

69. Inman, P. Pyrrhic victory for the new army of self-employed. The Guardian, 3 February 2014; 23.

70. Trade Union Congress. Four in Five Jobs Created Since 2010 Have Been in Low Paid Industries; Trade Union Congress: London, UK, 2013.

71. Allen, M. Hard Labour: Young People Moving into Work in Difficult Times; Radicaled: London, UK, 2015.

72. Birdwell, J.; Grist, M.; Margo, J. The Forgotten Half; Demos: London, UK, 2011.

73. Gardiner, L.; Gregg, P. Study, Work, Progress, Repeat? Resolution Foundation: London, UK, 2017.

74. Egerton, M.; Savage, M. Age stratification and class formation: A longitudinal study of the social mobility of young men and women, 1971-1991. Work Employ. Soc. 2000, 14, $23-49$.

75. Smith, D.J. Changes in transitions: The role of mobility, class and gender. J. Educ. Work 2009, 22, 369-390. [CrossRef]

76. Roberts, K. Regime change: Education to work transitions in England, 1980s-2020. J. Appl. Youth Stud. 2020. [CrossRef]

77. Clark, T.; Heath, A. Hard Times: The Divisive Toll of the Economic Slump; Yale University Press: Cambridge, MA, USA, 2014.

78. Commission on Living Standards. Gaining from Growth; Resolution Foundation: London, UK, 2012.

79. Institute for Employment Research and Institute for Fiscal Studies. Who Gains from Growth? Living Standards in 2020; Resolution Foundation: London, UK, 2012.

80. Jenkins, S.P. The Income Distribution in the UK: A Picture of Advantage and Disadvantage; ISER Working Paper 2015-1; Institute for Social and Economic Research, University of Essex: Colchester, UK, 2015.

81. Savage, M.; Bagnall, G.; Longhurst, B. Ordinary, ambivalent and defensive: Class identities in the northwest of England. Sociology 2001, 35, 875-892. [CrossRef]

82. Conley, H. A state of insecurity: Temporary work in the public services. Work Employ. Soc. 2002, 16, 725-737. [CrossRef]

83. Goldthorpe, J.H.; Mills, C. Trends in intergenerational class mobility in modern Britain: Evidence from national surveys, 1972-2005. Natl. Inst. Econ. Rev. 2008, 205, 83-100. [CrossRef]

Publisher's Note: MDPI stays neutral with regard to jurisdictional claims in published maps and institutional affiliations. 